\title{
Effectiveness of Trihalomethane (THM) Precursors Removal in Groundwater Using Coagulant-Disinfectant
}

\author{
Nurul Hana Mokhtar Kamal ${ }^{1,2, *}$, Nur Izyan Muhamad Jeffri ${ }^{1}$, Hamidi Abdul \\ Aziz ${ }^{1,2}$
}

${ }^{1}$ School of Civil Engineering, Engineering Campus, Universiti Sains Malaysia, 14300 Pulau Pinang, MALAYSIA

${ }^{2}$ Water Security Cluster, Science and Engineering Research Centre, Engineering Campus, Universiti Sains Malaysia, 14300 Pulau Pinang, MALAYSIA

*Corresponding Author

DOI: https://doi.org/10.30880/ijie.2019.11.01.014

Received 10 June 2018; Accepted 17 September 2018; Available online 10 May 2019

\begin{abstract}
Trihalomethanes (THMs) is a disinfection byproduct (DBP) which forms when disinfectants react with natural organic matter (NOM) in treated drinking water. The coagulation process using ferric salts was able to remove NOM, a DBP precursor, effectively. This study method included the combination of coagulants (ferricbased) with disinfectant(s), to speed up the treatment process in emergency applications. Groundwater samples were treated using either ferric sulphate or ferric chloride, and chlorine in a series of jar tests. Ferric sulphate application showed a good turbidity removal (50.51\%) while $\mathrm{UV}_{254}$ removal using ferric chloride was as high as $80.76 \%$. Most conditions at $\mathrm{pH} 5.5$ formed lower THMs compared to other $\mathrm{pH}$ levels, although the THM level at this $\mathrm{pH}$ still exceeded the limit set by authorities.
\end{abstract}

Keywords: Coagulation, disinfection, THM formation potential, NOM removal.

\section{Introduction}

Trihalomethanes (THMs) belong to the chlorinated DBP group which comprises four compounds; chloroform $\left(\mathrm{CHCl}_{3}\right)$, bromoform $\left(\mathrm{CHBr}_{3}\right)$, bromodichloromethane, BDCM, $\left(\mathrm{CHCl}_{2} \mathrm{Br}\right)$ and dibromochloromethane, DBCM, $\left(\mathrm{CHBr}_{2} \mathrm{Cl}\right)$ [1]. THMs are currently being regulated in most drinking water standards as they have been classified under Group B carcinogens (carcinogenic) which have reportedly caused bladder cancer and birth defects [1]-[3]. THM formation in treated water is a result of the reaction between the disinfectants, such as chlorine, used for water disinfection, with natural organic matters present in natural waters. THM precursors in water can be determined by quantifying these water quality parameters which include total organic carbon, dissolved organic carbon, UV absorbance at $254 \mathrm{~nm}$ wavelength $\left(\mathrm{UV}_{254}\right)$ or specific UV absorbance (SUVA) parameters [4]. According to the Ministry of Health, Malaysia, the maximum allowable limit for total THMs in drinking water is $1 \mathrm{mg} / \mathrm{L}$ and it should not exceed the limit to ensure safe and reliable drinking water [5].

Chlorine is the main disinfectant applied in Malaysian drinking water treatment plants due to its effectiveness in destroying bacteria and other pathogens, besides being more economical when compared with other types of oxidants [1]. Apart from that, using chlorine as a disinfectant at the right dose will ensure chlorine residue at the users' end.

Natural organic matter (NOM) is mostly present in natural water sources which can originate from different sources. Since NOM is a heterogenous mixture of organic compounds from the degradation of plant and animal residues, its content in natural water may vary depending on the sources [6]. NOM presence in natural waters is not toxic, however, it can cause aesthetic problems (colour, odour and taste) while also serving as a medium for other 
harmful contaminants to bind. NOM consists of hydrophobic and hydrophilic parts. Hydrophobic parts, which typically have high molecular weight, contain aromatic carbon, phenolic structures and conjugated double bonds, where hydrophobic acids (also called humic substances) have a major portion in aquatic NOM [7]. Hydrophilic NOM (nonhumic substances), which is more polar, consists of aliphatic carbon and nitrogenous compounds and usually have low molecular weight. According to Sillanpaa et al., coagulation process has been the top selection in removing NOM from source water as it has been proven to be efficient in removing DBP precursors [8], where metallic-based coagulants are the popular choice.

Two metal salts; ferric and aluminium salts, are most widely used [9] as they are low-cost and efficient in removing turbidity and colour in water in wastewater treatment plants [10]. Aluminium salts are more efficient in removing colour and turbidity, compared to ferric salts [7]. Nonetheless, a few past researchers found that the latter was more efficient in removing NOM compared to the former [11], [12]. Thus, ferric salts would be a more suitable choice to be applied if the main objective is to remove NOM in source water.

Typically, coagulation-flocculation and disinfectant processes are separated into different stages to ensure that the reaction at each stage has been completed. However, in cases of natural disasters or even in rural areas where source water is available but with no proper treatment plant, it is a better idea to provide a simple and rapid treatment method to generate clean and safe drinking water. Therefore, this study aims to determine the best coagulant dosage to be applied simultaneously with disinfectant under different $\mathrm{pH}$, to remove THM precursors. Apart from that, the formation of THM was compared to the drinking water quality standard to determine if this combination is suitable for rapid water treatment.

\section{Methodology}

This research involved groundwater sampling and the samples were later subjected to jar testing that applied simultaneous coagulation and disinfection processes as the THM formation potential (THMFP) test.

\subsection{Sampling Site and Analysis}

This study extracted groundwater sample from a borehole located in Universiti Sains Malaysia, Pulau Pinang (coordinate location of $5^{\circ} 08^{\prime} 50.5^{\prime \prime} \mathrm{N}, 100^{\circ} 29^{\prime} 34.7 \mathrm{E}$ ). The depth of the borehole is $43.575 \mathrm{~m}$ with a diameter of 0.2 $\mathrm{m}$. It is located just $1 \mathrm{~km}$ away from the Kerian River. It was reported previously in a study by Akbar that this groundwater had elevated organic matter content that might be due to surface water intrusion [14]. Before sampling, the groundwater was purged for two hours to make sure the readings for water quality was stabilised. Submersible pump was used to purge the borehole. This is mainly to make sure the variations in the water quality parameter of the raw water is small (less than $10 \%$ differences between the readings). The water sample was stored at $4{ }^{\circ} \mathrm{C}$ until analysis began. Sampling works were carried out from March till May 2017. The parameters tested for the raw water included $\mathrm{pH}$, temperature, $\mathrm{UV}_{254}$, and turbidity. $\mathrm{UV}_{254}$ is a measurement of the amount of light absorbed by organic compounds, specifically aromatic. In water sample, $\mathrm{UV}_{254}$ also indicates the concentration of organic matter, especially those containing aromatic rings. All parameters were tested according to the Standard Method for the Examination of Water and Wastewater (Standard Method).

\subsection{THM Formation Potential Test}

Ferric chloride $\left(\mathrm{FeCl}_{3}\right)$ and ferric sulphate $\left(\mathrm{Fe}_{2}\left(\mathrm{SO}_{4}\right)_{3}\right)$ were chosen as coagulants for this study as ferric-based salts were proven to be more efficient in removing NOM $[12,13]$. Jar tests were carried out with either $\mathrm{FeCl}_{3}$ or $\mathrm{Fe}_{2}\left(\mathrm{SO}_{4}\right)_{3}$ as coagulants at various $\mathrm{pH}$ and coagulant dosages, where the $\mathrm{pH}$ range was between $4-6$ and the coagulant dosage was between $0-100 \mathrm{mg} / \mathrm{L}$. Control sample (no coagulant dosage) were carried out for each $\mathrm{pH}$ conditions. Coagulants were added simultaneously with chlorine $(5 \mathrm{mg} / \mathrm{L}$ dose) after $\mathrm{pH}$ adjustments were carried out. Prior to dosing, chlorine stock solution was prepared from sodium hypochlorite at $1000 \mathrm{mg} / \mathrm{L}$ and will be tested for the initial condition before dosing. The mixing was carried out as follows: rapid mixing at $300 \mathrm{rpm}$ (30 sec) followed by $250 \mathrm{rpm}(2 \mathrm{mins})$, and later slow mixing at $40 \mathrm{rpm}(10 \mathrm{mins})$ before the samples were left to settle for $20 \mathrm{mins}$. Then, the supernatant was extracted for THM quantification.

\subsection{Sample Extraction and THM Quantification}

Before THMs compound can be determined, all samples need to be extracted. $30 \mathrm{~mL}$ of sample was extracted following a liquid-liquid extraction (LLE) method as modified from the USEPA 551.1 method [15]. In a $60 \mathrm{ml}$ glass extraction vial equipped with a PTFE-lined screw cap, the sample was adjusted to a $\mathrm{pH}$ of $\sim 3.5$ (under acidic condition) using $\mathrm{H}_{2} \mathrm{SO}_{4}$ dilution followed by the addition of $1 \mathrm{~g}$ copper sulphate and $10 \mathrm{~g}$ pre-baked sodium sulphate [15]. $3 \mathrm{~mL}$ of Methyl tert-butyl ether (MTBE) with $1 \mu \mathrm{g} / \mathrm{ml}$ bromofluorobenzene (internal standard) was added as the extraction solvent. The extraction vial was shaken vigorously by hand for approximately 4 mins and was allowed to rest for approximately 2 mins to let the water and MTBE phases separate. An aliquot of the extract was removed by using a glass pipette and transferred to a $2 \mathrm{~mL} \mathrm{GC}$ vial and which was subsequently quantified by gas chromatography with 
mass spectrometry, GC-MS (Agilent 7890 GC with 5975C MSD ChemStation) [15]. The instrument settings areas seen in Table 1.

Table 1 - GC-MS Settings Details

\begin{tabular}{ll}
\hline GC: & Agilent 7890A \\
Columns: & Restek Rxi-5 Sil MS column of dimensions $30 \mathrm{~m}$ x $0.25 \mathrm{~mm}$ x \\
& $0.25 \mu \mathrm{M}$. \\
Carrier Gas: & Helium constant flow at $1 \mathrm{~mL}$ per minute \\
Injection & $3 \mathrm{~mL}$, splitless \\
Volume: & Initial temperature at $35^{\circ} \mathrm{C}$ for 3 min, then $20^{\circ} \mathrm{C}$ per minute to \\
\hline Temperature Programmes: & $150^{\circ} \mathrm{C}, 35^{\circ} \mathrm{C}$ per minute to $300^{\circ} \mathrm{C}$ and hold for 5 minutes \\
\hline Oven: & $250^{\circ} \mathrm{C}$ \\
Injector: & Agilent $5975 \mathrm{C}$ \\
Mass & \\
Spectrometer: & $150^{\circ} \mathrm{C}$ \\
MS Quad & $230^{\circ} \mathrm{C}$ \\
Temperature: & Ion Source:
\end{tabular}

\section{Results and Discussion}

The groundwater site was selected with prior knowledge from Akbar [14] that it contained higher NOM compared to usual groundwater. This was to allow the maximum THM formation potential that might happen in the presence of elevated NOM levels in source water. Table 2 summarises the characteristics of the groundwater which had been sampled for four times from March till May 2017. $\mathrm{pH}$ and turbidity levels were still within the limit stated by the Ministry of Health, Malaysia [5]. When compared with previous research, $\mathrm{UV}_{254}$ values in this study were on the higher range compared to other groundwater samples and surface water from past research [16-18].

Table 2 Groundwater characteristics

\begin{tabular}{lcccc}
\hline Parameters & Unit & Min value & Max Value & Average \\
\hline $\mathrm{pH}$ & & 6.58 & 7.64 & 6.92 \\
Temperature & ${ }^{\circ} \mathrm{C}$ & 28.33 & 29.09 & 28.47 \\
Turbidity & $\mathrm{NTU}$ & 9.06 & 42.53 & 23.7 \\
$\mathrm{UV}_{254} \mathrm{~nm}$ & $\mathrm{~cm}^{-1}$ & 1.002 & 1.328 & 1.161 \\
\hline
\end{tabular}

Fig. 1 shows the trends in turbidity removal at different $\mathrm{pH}$ levels and $\mathrm{FeCl}_{3}$ dosages. The trends indicated that a higher dosage produced higher percentage of removal; however optimum dosage could not be determined as the percentage of removal kept increasing with the dosage. The highest percentage removal was $44.61 \%$ with $\mathrm{FeCl}_{3}$ at 100 $\mathrm{mg} / \mathrm{L}$ at a $\mathrm{pH}$ of 5.5 (control sample $-44.31 \mathrm{NTU}$, final turbidity $-26.29 \mathrm{NTU}$ ). To achieve higher removal, higher coagulant dosage should be tested in order to obtain the optimum $\mathrm{pH}$ and dosage. The highest removal at $44.61 \%$ was still far from reaching the allowable Malaysian drinking water standard (5 NTU). However, with higher dosage it will be less economical. Thus, using $\mathrm{FeCl}_{3}$ as coagulant simultaneously with chlorine at the tested $\mathrm{pH}$ might need additions/alterations of some other conditions to boost the turbidity removal.

Fig. 2 shows the percentage of turbidity removal using $\mathrm{Fe}_{2}\left(\mathrm{SO}_{4}\right)_{3}$ as the coagulant. There is a difference in the removal trend compared to $\mathrm{FeCl}_{3}$. By using $\mathrm{Fe}_{2}\left(\mathrm{SO}_{4}\right)_{3}$, the optimum value obtained was when the pH was 5.0 at the dosage of $80 \mathrm{mg} / \mathrm{L}$. During optimum conditions, the percentage of removal was slightly higher than removal rates recorded when using $\mathrm{FeCl}_{3}$, at 50.51\% (final turbidity - $23.49 \mathrm{NTU}$ ). However, the initial turbidity for the $\mathrm{Fe}_{2}\left(\mathrm{SO}_{4}\right)_{3}$ experiments were at $46.06 \mathrm{NTU}$, just slightly higher than the initial turbidity for $\mathrm{FeCl}_{3}, 44.31$ NTU. Thus, when comparing both coagulants, the percentage of removal obtained showed only a slight difference. $\mathrm{However}_{\mathrm{H}} \mathrm{FeCl}_{3}$ showed the percentage turbidity removal continued to increase even at the same coagulant dose $(100 \mathrm{mg} / \mathrm{L}) \mathrm{compared}$ to ferric sulphate. It can be concluded that the application of $\mathrm{Fe}_{2}\left(\mathrm{SO}_{4}\right)_{3}$ is more economical due to higher removal of turbidity at lower dosage, however higher turbidity removal can be expected with higher dosage of $\mathrm{FeCl}_{3}$. According to a study by Ibrahim and Aziz [14], overdosing the coagulant results in a substantial increase in the amount of generated sludge and a decrease in $\mathrm{pH}$. This might explain the decreases in removal after $80 \mathrm{mg} / \mathrm{L}$ for all cases when applying $\mathrm{Fe}_{2}\left(\mathrm{SO}_{4}\right)_{3}$ as coagulant. 


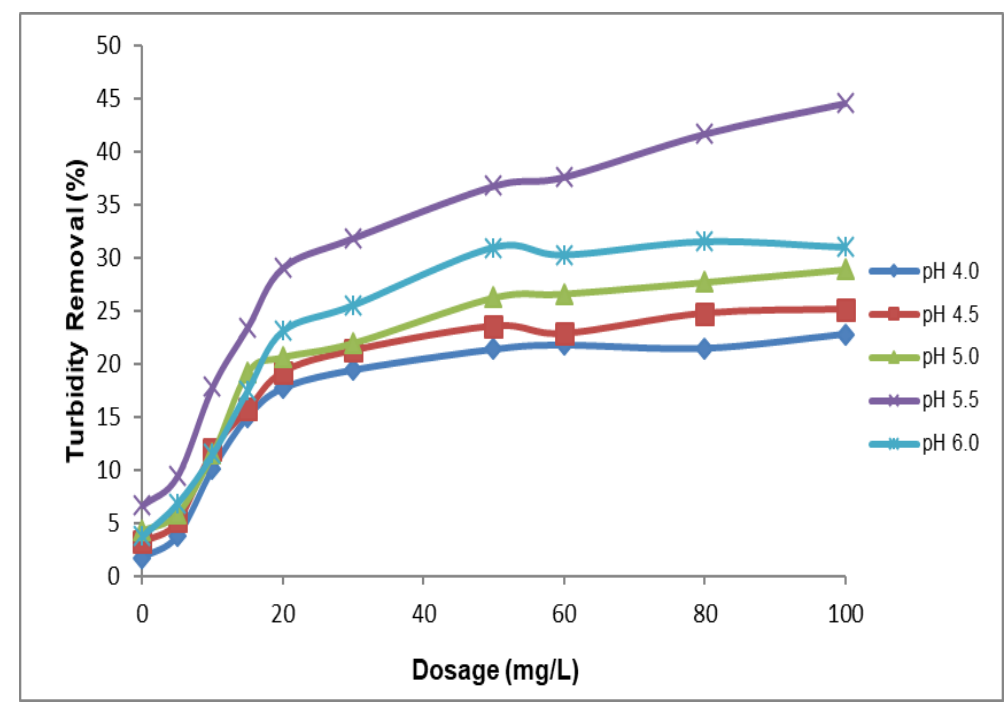

Fig. 1 - Percentage of turbidity removal using $\mathrm{FeCl}_{3}$ as coagulant at various conditions $\mathrm{pH}$ and coagulant dose

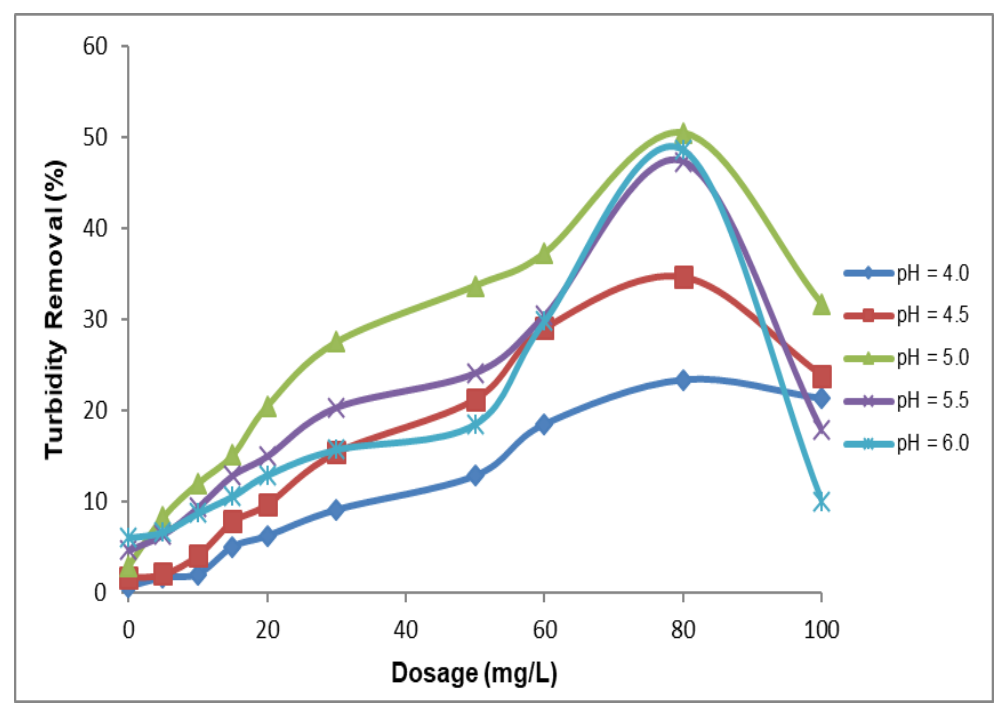

Fig. 2 - Percentage of turbidity removal using $\mathrm{Fe}_{2}\left(\mathrm{SO}_{4}\right)_{3}$ as coagulant at various conditions $\mathrm{pH}$ and coagulant dose

Fig. 3 shows the percentage of $U_{254}$ removal, which produced two peaks at $10 \mathrm{mg} / \mathrm{L}$ and $50 \mathrm{mg} / \mathrm{L}$. The first peak shows a low removal rate compared to the second peak illustrating that $\mathrm{FeCl}_{3}$ was effective with only $10 \mathrm{mg} / \mathrm{L}$ as it had removed almost $40 \%$ of $\mathrm{UV}_{254}$. However, the best value for $\mathrm{UV}_{254}$ removal was chosen at pH 5.5 set at a dosage of 50 $\mathrm{mg} / \mathrm{L}$, due to higher removal. The highest percentage removal was at $80.76 \%$. As compared to previous research, $\mathrm{FeCl}_{3}$ reached until $55 \% \mathrm{UV}_{254}$ removal at dosage of $80 \mathrm{mg} / \mathrm{L}$ [4]. Furthermore, according to Sulaymon et al. [19], $\mathrm{FeCl}_{3}$ obtained $\mathrm{UV}_{254}$ removal about $54 \%$ at dosages greater than $40 \mathrm{mg} / \mathrm{L}$. It showed that, $\mathrm{UV}_{254}$ removal obtained in this study achieved higher removal rates than previous studies.

Based on Fig. 4, $\mathrm{Fe}_{2}\left(\mathrm{SO}_{4}\right)_{3}$ shows lower percentage removal compared to $\mathrm{FeCl}_{3}$ but at a higher coagulant dose. At $\mathrm{pH} 5$, about $57.63 \%$ of $\mathrm{UV}_{254}$ was removed when using $\mathrm{Fe}_{2}\left(\mathrm{SO}_{4}\right)_{3}$ compared to $78.84 \%$ when using $\mathrm{FeCl}_{3}$. Optimal removal obtained was at $\mathrm{pH} 5.0$ and dosage of $80 \mathrm{mg} / \mathrm{L}$. At lower $\mathrm{pH}$ of 4.0 and $4.5, \mathrm{Fe}_{2}(\mathrm{SO} 4)_{3}$ recorded removal trend of less than half the amount of removal at the higher $\mathrm{pH}$, at all dosage. By comparing both coagulants, $\mathrm{FeCl}_{3}$ was a more effective coagulant as it removed higher percentage of $\mathrm{UV}_{254}$. According to Crittenden et al. [20], it was recorded that for treatment plants $\mathrm{Fe}_{2}\left(\mathrm{SO}_{4}\right)_{3}$ application mainly needs higher dosage, on weight basis, $(20-250 \mathrm{mg} / \mathrm{L}) \mathrm{compared}$ to $\mathrm{FeCl}_{3}(5-150 \mathrm{mg} / \mathrm{L})$, which shown that normally $\mathrm{Fe}_{2}\left(\mathrm{SO}_{4}\right)_{3}$ are needed in higher quantity to obtain good removal. 


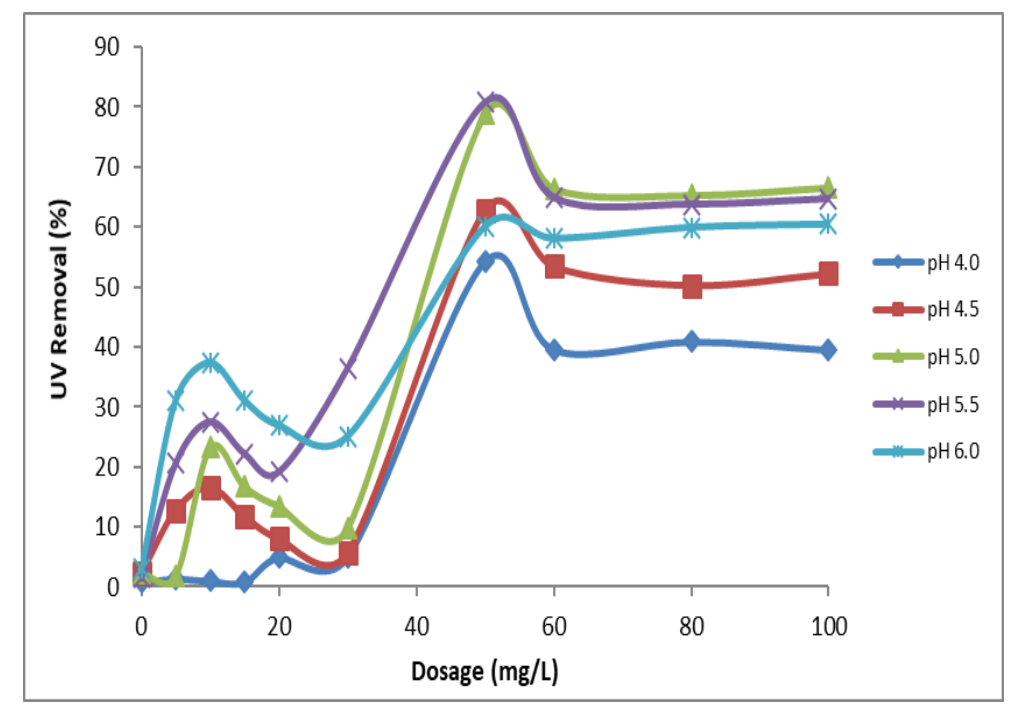

Fig. 3 - Percentage of $\mathrm{UV}_{254}$ removal using $\mathrm{FeCl}_{3}$ as coagulant at various conditions $\mathrm{pH}$ and coagulant dose

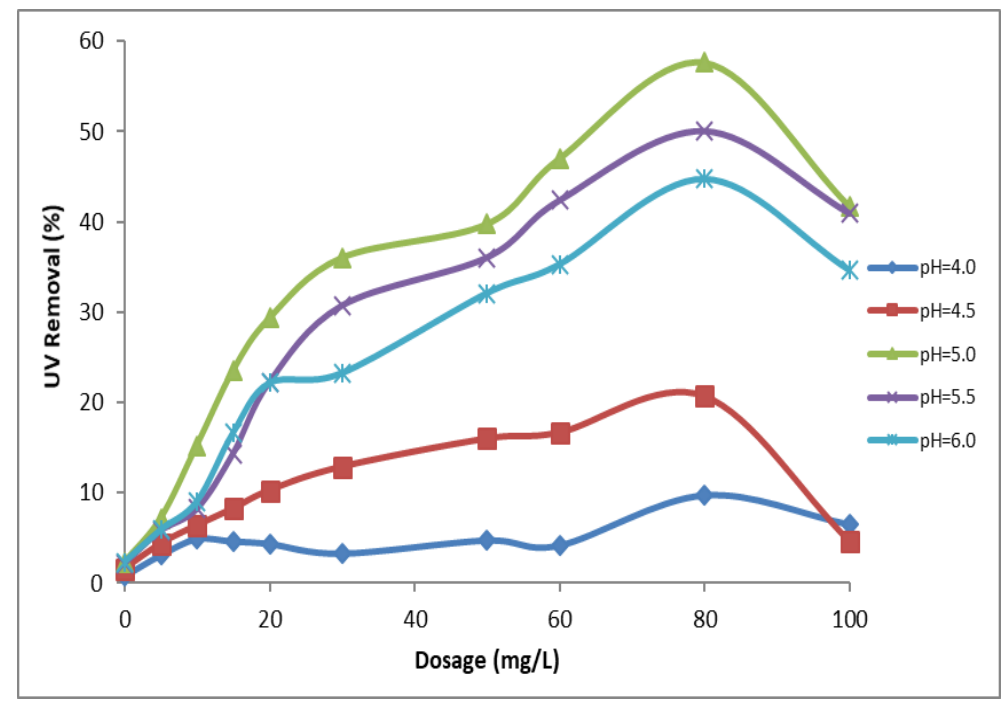

Fig. 4 - Percentage of $\mathrm{UV}_{254}$ removal using $\mathrm{Fe}_{2}\left(\mathrm{SO}_{4}\right)_{3}$ as coagulant at various conditions $\mathrm{pH}$ and coagulant dose

With regards to the removal of turbidity and $\mathrm{UV}_{254}, \mathrm{pH} 5.0$ and 5.5 are the best condition for removal for both $\mathrm{FeCl}_{3}$ and $\mathrm{Fe}_{2}\left(\mathrm{SO}_{4}\right)_{3}$. Thus, THM formation potential experiments were carried out for these two $\mathrm{pH}$ levels to determine if THM formation would exceed the standard limits. Fig. 5 shows THM formation at $\mathrm{pH} 5$ for both coagulants. All THM compounds were formed at this stage and BDCM was the dominant compound for both coagulants. For $\mathrm{Fe}_{2}\left(\mathrm{SO}_{4}\right)_{3}$, BDCM formed the highest concentration which exceeded the limit specified by the Ministry of Health and WHO; as more than $0.060 \mathrm{mg} / \mathrm{L}$ formed, followed by chloroform, DBCM and bromoform. For $\mathrm{FeCl}_{3}, \mathrm{BDCM}$ was the major compound formed at the set concentrations which almost exceeded the limit at all dosages except at $5 \mathrm{mg} / \mathrm{L}$ $(0.087 \mathrm{mg} / \mathrm{L})$ while chloroform and bromoform were not as high. Even though the percentage removal for $\mathrm{FeCl}_{3} \mathrm{was}$ lower compared to $\mathrm{Fe}_{2}\left(\mathrm{SO}_{4}\right)_{3}$, the dosage to reach the optimum removal was found to be lower for $\mathrm{FeCl}_{3}$ compared to $\mathrm{Fe}_{2}\left(\mathrm{SO}_{4}\right)_{3}$.

By referring to Fig. 6, higher chloroform formed in groundwater at $\mathrm{pH} 5.5$ for $\mathrm{Fe}_{2}\left(\mathrm{SO}_{4}\right)_{3}$ application $(0.16 \mathrm{mg} / \mathrm{L}$ at $50 \mathrm{mg} / \mathrm{L}$ ), whereas when $\mathrm{FeCl}_{3}$ was applied BDCM had higher concentrations. At the same dose of $50 \mathrm{mg} / \mathrm{L}$ chloroform was reduced to less than $0.01 \mathrm{mg} / \mathrm{L}$, while $\mathrm{BDCM}$ formed was at $0.060 \mathrm{mg} / \mathrm{L}$, which is close to the maximum detection limit. However, BDCM shows a gradual decrease after reaching the highest peak. $\mathrm{For}_{\mathrm{FeCl}}$, all THM compounds formed at lower concentrations compared to $\mathrm{Fe}_{2}\left(\mathrm{SO}_{4}\right)_{3}$. Only BDCM exceeded the limit while other THM compounds did not. Based on Fig. 5 and Fig. 6, the application of $\mathrm{FeCl}_{3}$ with chlorine might have the ability to reduce chloroform formation in the treated water. However, BDCM might be slightly elevated in most cases. 
At both pH levels, mostly all four THM compounds were formed, though at different concentrations. By comparing both coagulants with various conditions of $\mathrm{pH}$ and dosages, $\mathrm{pH} 5.5$ showed the least formation where most of the compounds formed were still under the limit specified by the two guidelines. This means that THMs formation potential was the least at $\mathrm{pH}$ of 5.5. With regards to total THM (TTHM) weight basis, it is still considered unsafe for prolonged use as the TTHM weight exceeded the limit stated ( $>1 \mathrm{mg} / \mathrm{L}$ of TTHM). If consumers drink or use this water for other purposes at an extended period, there is a high health risk.
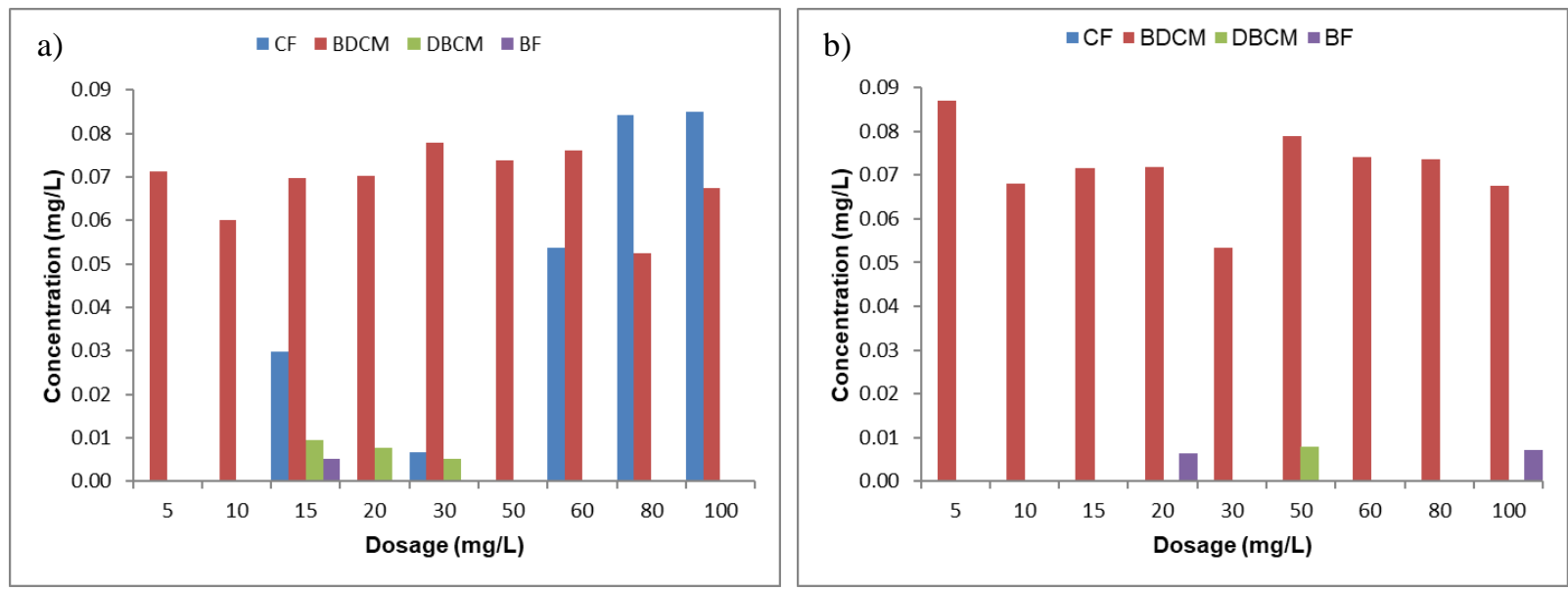

Fig. 5 - Occurrence of THM compound in groundwater at $\mathrm{pH} 5$ using a) $\mathrm{Fe}_{2}\left(\mathrm{SO}_{4}\right)_{3}$ and b) $\mathrm{FeCl}_{3}$
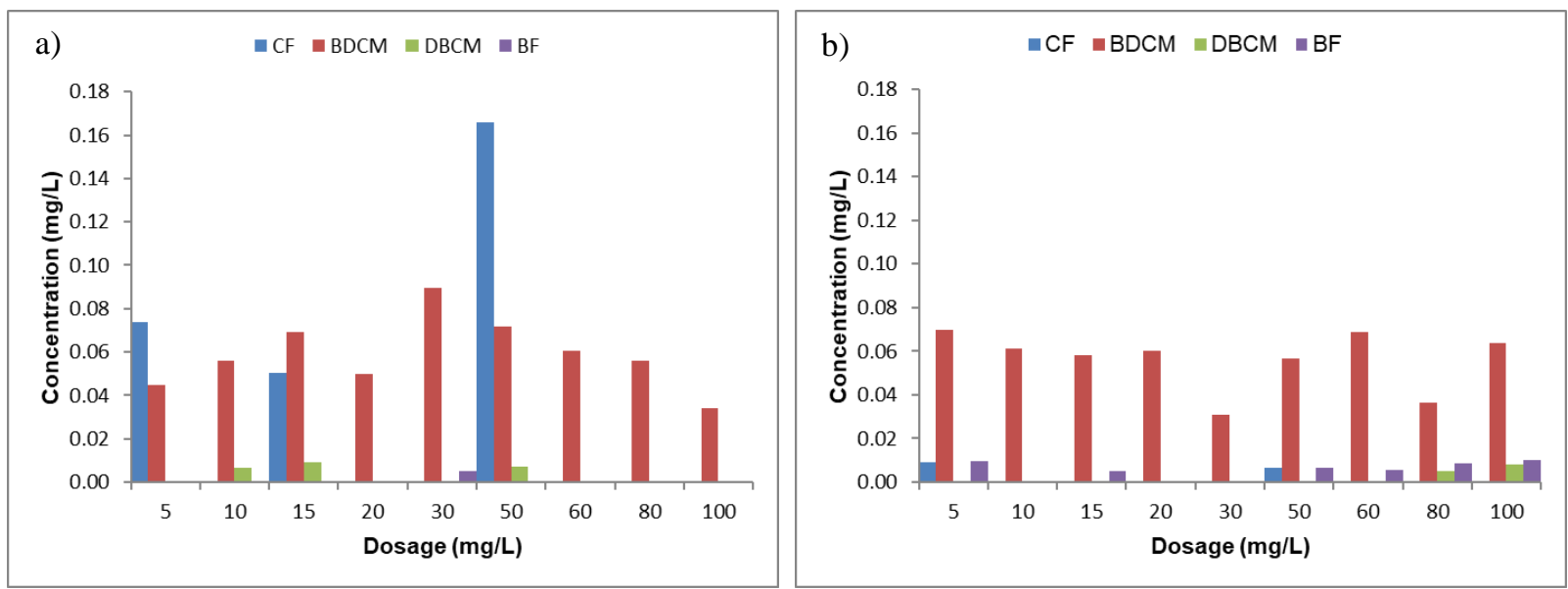

Fig. 6 - Occurrence of THM compound in groundwater at pH 5.5 using a) $\mathrm{Fe}_{2}\left(\mathrm{SO}_{4}\right)_{3}$ and b) $\mathrm{FeCl}_{3}$

\section{Summary}

This study was conducted to determine the effectiveness of removing THM precursors by using simultaneous coagulant-disinfectants. Groundwater was tested at different $\mathrm{pH}$ levels and coagulant dosages. Generally, $\mathrm{Fe}_{2}\left(\mathrm{SO}_{4}\right)_{3}$ application at all the $\mathrm{pH}$ tested shown pattern with optimal conditions, however $\mathrm{FeCl}_{3}$ application shown better removal with increment of dosage until $100 \mathrm{mg} / \mathrm{L}$. For $\mathrm{Fe}_{2}\left(\mathrm{SO}_{4}\right)_{3}$, the highest percentage of removal was at $50.51 \%$ and $57.63 \%$ which indicated highest turbidity and $\mathrm{UV}_{254}$ removal, respectively. This was by applying $\mathrm{Fe}_{2}\left(\mathrm{SO}_{4}\right)_{3}$, at the optimal conditions which was at $\mathrm{pH} 5$ and dosage $80 \mathrm{mg} / \mathrm{L}$ for both parameters, turbidity and $\mathrm{UV}_{254}$. $\mathrm{For} \mathrm{FeCl}_{3}$, the highest percentage of removal was $44.61 \%$ and $80.76 \%$ for turbidity and $\mathrm{UV}_{254}$, respectively. However, turbidity removal did not show any obvious peak but it could be concluded from the graph that higher dosage of coagulant produced higher turbidity removal. The optimum condition for $\mathrm{UV}_{254}$ removal was at $\mathrm{pH} 5.5$ and dosage of $50 \mathrm{mg} / \mathrm{L}$. It would be better to also have dissolved organic (DOC) data so that the correlation of THM formation can be compared with the DOC value. However, due to certain limitations, the authors were not able to present it here. On weight basis, most of the water samples tested at $\mathrm{pH} 5$ and 5.5, which recorded the best removal rate, exceeded the TTHM limit specified by the Malaysian Drinking Water Quality Standard. 


\section{Acknowledgement}

The authors would like to express their gratitude to Universiti Sains Malaysia (USM) for providing the Short Term Grant No. 304.PAWAM.60313031 - Investigation of Source Water Characteristics and the Occurrence of Disinfected By-Products (DBPs) in Drinking Water to carry out the research works and subsequently producing this paper.

\section{References}

[1] Kanchanamayoon, W. (2015). Sample preparation methods for the determination of chlorination disinfection byproducts in water samples. Chromatographia, 78, 1135-1142.

[2] Shafiee, M., Reza, M. and Taghavi, L. (2012). Health effects of trihalomethanes as chlorinated disinfection by products: A review Article. World Academy of Science, Engineering and Technology, 68, 2090-2096.

[3] Chang, H. H., Tung, H. H., Chao, H. H. and Wang, G. S. (2010). Occurrence of haloacetic acids (HAAs) and trihalomethanes (THMs) in drinking water of Taiwan, Environmental Monitoring and Assessment, 162(1-4), 237250.

[4] Rizzo, L., Belgiorno, V., Gallo, M. and Meriç, S. (2005). Removal of THM precursors from a high-alkaline surface water by enhanced coagulation and behaviour of THMFP toxicity on D. magna. Desalination, 176, 177-188.

[5] Ministry of Health Malaysia (2010). Drinking water quality standard. Drinking water quality surveillance programme. Putrajaya: Engineering Services Division.

[6] Metsämuuronen, S., Sillanpää, M., Bhatnagar, A. and Mänttäri, M. (2014). Natural organic matter removal from drinking water by membrane technology. Separation and Purification Reviews, 43(1), 1-61.

[7] Matilainen, A., Vepsäläinen, M. and Sillanpää, M. (2010). Natural organic matter removal by coagulation during drinking water treatment: A review. Advances in Colloid and Interface Science, 159(2), 189-197.

[8] Sillanpää, M., Ncibi, M. C., Matilainen, A. and Vepsäläinen, M. (2018). Removal of natural organic matter in drinking water treatment by coagulation: A comprehensive review. Chemosphere, 190, 54-71.

[9] Bahadori, A., Clark, M. and Boyd, B. (2013). Essentials of water systems design in the oil, gas, and chemical processing industries. New South Wales: Springer.

[10] Bratby, J. (2006). Coagulation and flocculation in water and wastewater treatment (2nd Edition). London: IWA Publishing.

[11] Gonzalez-Torres, A., Putnam, J., Jefferson, B., Stuetz, R. M. and Henderson, R. K. (2014). Examination of the physical properties of Microcystis aeruginosa flocs produced on coagulation with metal salts. Water Research, 60, 197-209.

[12]Zhao, Y., Xiao, F., Wang, D., Yan, M. and Bi, Z. (2013). Disinfection byproduct precursor removal by enhanced coagulation and their distribution in chemical fractions. Journal of Environmental Sciences (China), 25(11), 22072213.

[13] Akbar, N. A., Abdul Aziz, H. and Adlan, M. N. (2015). Iron and manganese removal from groundwater using high quality limestone. Applied Mechanics and Materials, 802, 460-465.

[14] Ibrahim, N. and Aziz, H. A. (2014). trends on natural organic matter in drinking water sources and its treatment. International Journal of Scientific Research in Environment Sciences, 2, 94-106.

[15] USEPA (1995). Method 551.1: Determination of chlorination disinfection byproducts, chlorinated solvents , and halogenated pesticides/ herbicides in drinking water by liquid-liquid extraction and gas chromatography with electron-capture detection. Environmental Protection, pp 1-61.

[16] Bazrafshan, E., Biglari, H. and Kord Mostafapour, F. (2012). Determination of hydrophobic and hydrophilic fractions of natural organic matter in raw water of Zahedan water treatment plant. Journal of Health Scope, 1(1), 25-28.

[17] Golea, D. M., Upton, A., Jarvis, P., Moore, G., Sutherland, S., Parsons, S. A. and Judd, S. J. (2017). THM and HAA formation from NOM in raw and treated surface waters. Water Research, 112, 226-235.

[18] Tubić, A., Agbaba, J., Dalmacija, B., Perović, S. U., Klašnja, M., Rončević, S. and Ivančev-Tumbas, I. (2011). Removal of natural organic matter from groundwater using advanced oxidation processes at a pilot scale drinking water treatment plant in the Central Banat Region (Serbia). Ozone: Science and Engineering, 33(4), 267-278.

[19] Sulaymon, A. H., Ali, A. F. M. and Al-Naseri, S. K. (2009). Natural organic matter removal from Tigris River water in Baghdad, Iraq. Desalination, 245, 155-168.

[20] Crittenden, J., Trussell, R. R., Hand, D., Howe, K. and Tchobanoglous, G. (2012). MWH's water treatment: Principles and design (3rd Edition). Hoboken: John Wiley and Sons. 